Cahiers $d u$ MONDE RUSSE

\section{Cahiers du monde russe}

Russie - Empire russe - Union soviétique et États indépendants

55/3-4 | 2014

Varia

\title{
Wendy Rosslyn, Alessandra Tosi, eds., Women in Nineteenth-Century Russia, Lives and Culture
}

\section{Michelle Lamarche Marrese}

\section{OpenEdition}

\section{Journals}

Electronic version

URL: http://journals.openedition.org/monderusse/8043

DOI: $10.4000 /$ monderusse. 8043

ISSN: $1777-5388$

\section{Publisher}

Éditions de l'EHESS

\section{Printed version}

Date of publication: 1 July 2014

Number of pages: $377-379$

ISBN: 978-2-7132-2441-6

ISSN: $1252-6576$

\section{Electronic reference}

Michelle Lamarche Marrese, « Wendy Rosslyn, Alessandra Tosi, eds., Women in Nineteenth-Century Russia, Lives and Culture », Cahiers du monde russe [Online], 55/3-4 | 2014, Online since 10 April 2015, Connection on 24 September 2020. URL : http://journals.openedition.org/monderusse/8043; DOI : https://doi.org/10.4000/monderusse.8043

This text was automatically generated on 24 September 2020.

2011 


\title{
Wendy Rosslyn, Alessandra Tosi, eds., Women in Nineteenth-Century Russia, Lives and Culture
}

\author{
Michelle Lamarche Marrese
}

\section{REFERENCES}

Wendy ROSSLYN, Alessandra TOSI, eds. Women in Nineteenth-Century Russia, Lives and Culture, Cambridge : Open Book Publishers, 2012, 249 p.

1 Scholarly literature on the experience of women in Imperial Russia has grown considerably over the course of the last two decades. In Women in Nineteenth-Century Russia, Wendy Rosslyn and Alessandra Tosi have compiled a series of articles representing the range of this work and demonstrating the insight we have gained into Russian women's lives, as well as drawing attention to the work yet to be done. This collection is a useful survey of both the social and cultural history of Russian women in the nineteenth century, and brings together the work of many prominent researchers in the field.

2 The collective portrait that emerges from these essays is one of cautious optimism. The first three articles explore women's lives in the context of urban culture, peasant life, and religious observance. On the basis of petitions from unhappy wives who sought separation from their husbands (divorce remained virtually impossible until the end of the Imperial era), Barbara Engel concludes that social and geographical mobility encouraged women to seek new opportunities and greater autonomy as they made the transition from life in the village to life in an urban setting. She also points out, however, that the Imperial Chancellery for the Receipt of Petitions proved reluctant to liberate women from the tutelage of abusive husbands and continued to uphold the interests of the family over those of the individual. In a close reading of the letters of three literate peasant women, Christine Worobec argues that historians must abandon 
their search for a unified, "authentic" peasant culture (p. 50), and goes on to elaborate the diversity of worldviews that characterized the lives of women. Not surprisingly, spiritual matters loomed large in the letters she examines : indeed, Worobec argues, women predominated in the pilgrimages of the late nineteenth century and religion remained "paramount" (p.61) in shaping female identity. At the same time, she also remarks on the new significance of consumer culture and "upward mobility" for peasant women (p. 61). For women, the resurgence of devotional literature on the Virgin Mary in the late nineteenth and early twentieth centuries was particularly significant. Vera Shevzov traces the growing popularity of narratives of Mary's life, and offers a cogent analysis of how Marian literature became a central part of religious observance and inspiration for Russian women of all social classes.

3 Much of this collection is devoted to the elusive topic of women's participation in the realm of literature and the arts. As several authors acknowledge, uncovering feminine contributions in the cultural sphere is no easy task. As Rosalind Blakesley remarks, female artists did not become "an established part of the cultural fabric of Russia" ( $p$. 92) until the eve of the Revolution. Only in the 1840s did women win the opportunity to attend the Academy of Arts as auditors, who were banned from official exams and competitions, but became eligible for awards. Similarly, Philip Ross Bullock points out that the performance of music was central in the lives of elite women, yet women were barred from performing in public and little evidence of women's role as composers of music survives from the eighteenth and early nineteenth centuries. The same restrictions that applied to women performing music in public applied to the performing arts. As Julie Cassiday relates, noblewomen were free to take part in amateur and domestic theater, but women who performed in public were, overwhelmingly, serfs, whose appearance in public was closely associated with prostitution. As Cassiday observes, the serf actress, Praskov'ia Kovaleva, known as Zhemchugova ("The Pearl") and Ekaterina Semenova, who was also born into serfdom, not only achieved unusual prominence, but also embodied the "sentimental" narrative that "rewrote" the "hierarchy of master and serf as a utopian performance of loving equals" (p.152). Both were exceptional in enjoying the patronage of powerful noblemen-Zhemchugova eventually became the wife of Count Nikolai Sheremetev, dying two years after their marriage-as well as popular acclaim. Only in the last third of the nineteenth century did the actresses of the Silver Age become the "authors" of their image and narrative, rather than the subject of "a master plot composed by male patrons and spectators" (p. 158).

The sphere of literature offered, perhaps, the greatest scope for women to demonstrate their abilities and to achieve a degree of professionalism. As Arja Rosenholm and Irina Savkina point out in a lengthy overview of women's authorial opportunities over the course of the nineteenth century, it was N.M. Karamzin who actively encouraged women to participate in the realm of literature, as he "used gender in his campaign for a new literary language and a new literature" (p. 162). The "feminization" of literature thus fostered the phenomenon of women authors by legitimizing the "feminine" in the realm of writing; it also circumscribed what women might write, by creating rules for appropriate subject matter and language for women.

In a somewhat abrupt transition, this collection ends with an essay by Marianna Muravyeva on violence against women in the nineteenth century. Muravyeva's essay epitomizes the contradictions that characterized the lives of women of all classes in 
nineteenth-century Russia : ironically, the protection against rape that women had enjoyed under the legal regimes of seventeenth- and eighteenth-century Russia gave way to new definitions of "honor" and the desire of law makers to "turn a blind eye" to spousal abuse and to confine domestic abuse to the realm of the family (p.232). Although women did not relinquish their efforts to escape abusive husbands or to accuse those guilty of assault, as Muravyeva argues, "only those women who conformed to the prescribed standards of femininity could find justice" (p. 238).

6 The essays in this collection are thoroughly researched and clearly written ; they are, moreover, accessible to the non-specialist. It is worth noting that Open Book Publishers makes their work available on-line ; as a result, the articles in this book could be easily assigned in undergraduate courses. Although this volume does not address the experience of women in political life or their role in revolutionary politics, these articles are an excellent introduction to the experience of women in nineteenth-century Russia.

\section{AUTHORS}

\section{MICHELLE LAMARCHE MARRESE}

New York, New York 